Eva Ivanová,

Ing., CSc., Assistant Professor, Head of the Department of Economics and Economy, Faculty of Social and Economic Relations, Alexander Dubček University in Trenčín (Trenčín, Slovak Republic);

Marcel Kordoš,

Ing., PhD, Assistant Professor of the Department of Public Administration and Regional Economy, Faculty of Social and Economic Relations, Alexander Dubček University in Trenčín (Trenčín, Slovak Republic)

\title{
INNOVATION POLICY OF SMES IN SLOVAKIA IN THE CONTEXT OF EUROPEAN UNION INNOVATION POLICY
}

In the paper, the financial sources used by small and medium enterprises (SMEs) in Slovakia to finance innovation are identified. The sources that are essential for SMEs are determined. Types of innovation the small and medium enterprises are investing their sources in are found out. To conduct the survey questionnaire was used. The results were processed by means of the Chi-square test.

Keywords: innovation, financial sources, innovation policy, types of innovation

DOI: 10.21272/mmi.2017.3-20

Introduction. The industrial policy of the EU stresses the importance of promoting innovation among European companies as one of the key objectives of policy. This has led to the development of framework policies to promote pan-EU cooperation in R \& $D$ and other areas of technological development [7]. The development of a knowledge-based economy lies at the heart of these framework policies. The structuring of the European research area part of the program is seeking to build a European research base and accounts for approximately 16 per cent of the budget [26]. The framework programs are basically attempts to build panEU competence in major areas of research and technological developments and to promote a European ethos for such a research base. The framework programs have elements of seeking to build European champions in the area of research and technological competence [1]. The rationale for this would seem to be closely allied to the political integration driver of policy, as it is not clear that a European research and technological development base is preferable to a global or even a US orientated base [13]. Clearly, the USA is the technological leader in most of the thematic areas in the 6th Framework, hence linking to US research bases may be a more effective policy. If the objective is to develop European political institutions that foster research and technological development then the framework programs make sense. However, thus far the EU has not developed audit systems that test for the effectiveness, in terms of output relative to the US research base, of the framework programs [21]. Moreover, member states' governments maintain their own research and technological development programs often only marginally linked to the framework programs.

As highlighted by EU Industrial Policy, industry is crucial for EU competitiveness and innovation is a key factor in this regard. Industry accounts for $80 \%$ of Europe's exports. Some $65 \%$ of private sector research and development (R\&D) investment comes from manufacturing. Therefore, industrial modernization in Europe must be broad-reaching and include the successful commercialization of product and service innovations, the industrial exploitation of innovative manufacturing technologies, innovative business models. Studies show that those companies who prioritize innovation are also those who experience the highest increase in turnover [20]. Some $79 \%$ of companies that introduced at least one innovation since 2011 experienced an increase of their turnover by more than $25 \%$ by 2014 . Small and medium-sized enterprises are a particular target for innovation policy. The smaller the company is, the more it faces constraints to innovation or to the commercialization of its innovations. Some $63 \%$ of companies with between 1 and 9 employees declared having introduced at least one innovation since 
2011 , compared to $85 \%$ of companies with 500 employees or more. Some $71 \%$ of companies with between 1 and 9 employees encountered difficulties commercializing their innovations due to a lack of financial resources, compared to $48 \%$ of companies with 500 employees or more [6].

Micro, small and medium-sized enterprises are driving forces for the economy of each developed country, they play an important role in national economies development processes. Their importance lies in the fact that they can flexibly respond to market demands, contribute to increasing of innovation activities and competitive environment development, they generate employment, are adaptable and responsive to changes in economic environment [19]. SMEs significantly affect not only the economic and social situation of each country, but also play a very important role in regional development. The importance of this business segment is growing particularly in transition economies, therefore for its development it is necessary to create suitable business environment by using the tools of state and EU economic policy. In 2016 of the total number of businesses in Slovakia micro, small and medium-sized enterprises create a $99 \%$ share, they constitute $73.6 \%$ of employment and $52.8 \%$ of the total value added being created [6].

In previous researches the issue of Slovak innovation policy has been analyzed from the point of view as "The level of the innovation activity in the regions of Slovak Republic" in connection with regional effects. The EU regional policy has been characterized as „Assessment of innovation performance of Slovak regions" Also the issue of EU Innovation policy has been elaborated in previous studies from the aspect of other EU policies synergies "Interaction effects and impact of the EU Innovation policy within the creative industries" and has been illustrated as global political economy issue.

Literature overview and Theoretical background. The literature contains many publications that analyze the role, position and importance of small and medium enterprises (SMEs) for countries socioeconomic development. It is about analysis of their impact on development of various areas of economy, ways and forms of financing the development of small and medium-sized enterprises. There are also publications dealing with finding resources and presentation of research results in terms of innovation in particular countries.

The impact of SMEs on economic growth and socio-economic development can be found in professional literature in a relatively wide range. Gupta et al. write growth-oriented firms are a significant contributor in a nation's economic gain, but the concept of growth is different for different entrepreneurs [9]. Growth can be defined in terms of revenue generation, value addition, and expansion in terms of volume of the business. It can also be measured in the form of qualitative features like market position, quality of product, and goodwill of the customers.

Another issue being widely represented in a literature is the importance of innovation for the development of small and medium enterprises, the SMEs development strategy and the overall provision of resources for the growth of SMEs sector. According to Teirlinck \& Spithoven et al., SMEs lack absorptive capacity and hence technology intermediaries are useful for them [27]. They found that R\&Drelated activities may share around a half of a budget of a technology intermediary center and consequently these form an important element of absorptive capacity. Further argue that research cooperation and R\&D outsourcing often offer possibilities to complement the internal research resources but they need absorptive capacity and managerial skills of the internal R\&D personnel. Vojtovič states that SMEs' collaboration with external agencies increases their chances of launching products and services [30]. Collaboration of SMEs goes beyond science and technology and includes value chain partnerships that bring new knowledge bases which they can absorb easily.

These authors argue that lower credit facilities from the bank force the innovative firms to cut their budget on R\&D expenditure and that negatively affect new product and process innovation. Authors argue that easy access to bank finance can encourage SMEs to engage in R\&D activities and innovative new products that can help them to overcome market competition and help SMEs for long-term survival [18]. 
In professional circles, the concept of Open Innovation (OI) of Henry Chesbrough has been often discussed. Open innovation has become one of the most pertinent topics in innovation management studies as an alternative way of combining and integrating ideas, knowledge, and resources into business innovation processes. This approach suggests that firms use ideas and knowledge inflow and outflow purposefully in their innovation processes in order to foster internal innovation outcomes and expand markets [4]. Spithoven, Vanhaverbeke \& Roijakkers state open innovation practices in SMEs and medium-sized enterprises (SMEs) and how their use of $\mathrm{OI}$ and the resulting benefits differ from those of large enterprises [25]. The lack of resources in SMEs to engage in looking outward is said to be a barrier to OI, but at the same time this shortage is cited as a motive for looking beyond organizational boundaries for technological knowledge.

In theory the issue of financing SMEs is often discussed. According Madrid-Guijarro, Garcia-Perezde-Lema, Van Auken to reduce financing constraints on their innovation, SMEs should establish long relationships and low debt concentration with their main bank [17]. The more banks a firm is involved in, the greater its financing constraints. Lee, Sameen, Cowling write that the worsening in general credit conditions has been more pronounced for non-innovative firms with the exception of absolute credit rationing which still remains more severe for innovative firms [15].

Lesáková writes that small and medium enterprises have identified as one of the barriers for innovation the lack of innovation infrastructure [16]. Only a small part of small and medium enterprises in Slovakia possesses sufficient capacities as well as know- how for realization of all activities of innovative process, therefore it is needed to fill this gap with services of specialized consulting organizations. The aim is to create effective system of specialized consulting services for support of innovations. According to Haviernikova and Srovnalikova the quality of business environment is influenced by many factors [12]. The important one is the level of levies burden. High level of contribution burden within levies in case of small and medium-sized enterprises (SMEs) are very sensitive to changes in business environment which after a certain time are always reflected in quantitative characteristics of this sector.

Radas et al. confirms that receiving direct financial support from the government have more output from R\&D expenditures and that stimulates innovation propensity of the SMEs [22]. And firms that receiving both direct financial support and tax credit facility are superior in terms of innovation performance than the firms that do not receive any of the facilities. Government financial support can directly affect the innovation propensity of the SMEs because of financial incentives.

Brancati writes that SMEs both product and process innovation are hampered by lower level of credit in compared with firms those are financially flexible and smooth [3]. It is found that firms with financial constraints have approximately $30 \%$ less probability to engage in innovation in compared to financially solvent firms. Vermoesen et al. states that one from external sources for SMEs is venture capital, venture capital tends to target start-ups in a selected, but limited number of sectors [29]. Moreover, it entails equity-type investments and most often the involvement of the venture capitalist in business activities, which not all owners appreciate. In fact, in continental European countries the financial market is generally 'bank-based' rather than 'market-oriented', which stresses the role of banks in financing innovation activities and the challenge firms face to overcome information asymmetries. The issue of SMEs and innovation was dealt with in works by Cincera and Santos [5]. There are some other authors dealing with this issue, such as Foreman-Peck, J. (2013) [8], Hall, B.H. (2010) [11]; Tödtling, F., Kaufman, A. (2002) [28]; Habánik, J., Kordoš, M. \& Hošták, P. (2016) [10].

Paper objectives, Data collection and Methodology. The goal of this scientific paper is to identify the sources of funding for SMEs depending on the size of an enterprise and to determine the type of implemented innovation depending on the size category of an enterprise. To meet those objectives we conducted an empirical research, being executed in Slovak business environment in 2016. Research was conducted in Slovak Republic in the course of 2016. Research was conducted by the Alexandra 
Dubček University of Trenčín, Department of Economy and Economics. The survey was attended by a total of 658 enterprises classified as SMEs by size class employment.

In total, 676 questionnaires were collected, of which 18 were rejected (badly filled in). The research tool used for the study was the own questionnaire consisting of 38 questions and 7 questions included demographic data. The structure of the questionnaire allowed the authors to identify the group of questions concerning the most important conditions for the development of examined sector referring to Slovak business environment. The questions included in questionnaire were closed-ended (40) and semi-open questions (5). The questionnaire was filled in by owners or managers of enterprises from all over the Slovak Republic. The structure of SMEs was as follows: 55\% were micro-enterprises, $30 \%$ small enterprises and $15 \%$ medium-sized enterprises; $25 \%$ were enterprises making business less than 5 years, 24\% enterprises that run their business between 6 and 10 years and the rest were enterprises that have been rung business for more than 10 years $(52 \%)$. Of the total number of 658 enterprises, $20 \%$ are making business in manufacturing, $29 \%$ in trade, $5 \%$ in agriculture, $13 \%$ in construction, $6 \%$ in transport and $27 \%$ in other areas.

The chi-square test as a fundamental statistical method was used to meet the research goal and relating test hypotheses. It is a statistical non-parametric method being used to determine whether between the two characters there is a proven significant relationship. We have chosen the Chi-square test of proper correlation that allows us to test whether the observed frequencies differ from anticipated (expected) frequencies obtained from the pivot table. Anticipated frequencies were calculated. When testing the hypothesis we use a proper correlation test, which detects whether the observed variable has the distribution of certain type probabilities. Next the Kruskal-Walis non -parametric test has been used for testing. The conducted quantitative research allowed us to use statistical methods.

When analyzing the data from the questionnaire we proceeded according to Řezánková [23].The aim of the test is, according to Rimarčik to reveal if the medians differences being found in the sample of particular groups (according to the factor level) are statistically significant (between variables there is a relationship) or they can be just random (there is no relationship between variables) [24]. If the null hypothesis is to be rejected a detailed evaluation by means of Neményi method - a non-parametric multiple comparison method can be carried out if there are identical frequencies in groups.

Based on the above stated tests we find out the value of "p" and according to its results, we can either accept or reject the alternative hypothesis. The "p" value can take values from 0 to 1 . To put it in a nutshell, if the $p$-value is lower than the level of significance having been chosen (in social and economic sciences traditionally 0.05 ), the null hypothesis is to be rejected and the alternative hypothesis is to be adopted.

In terms of the objective being defined the following hypotheses have been set:

$\mathrm{H} 1$ : The type of funding to finance the business innovation is influenced by the size of an enterprise. We assume that there is a statistically significant functionality between the sources of financing the business innovation and the size of an enterprise.

H1a: Enterprises do not prefer different sources of funding on the equivalent basis. We assume that they prefer the EU funding.

$\mathrm{H} 2$ : The type of innovation being implemented is influenced by the size category of an enterprise. We assume that there is a statistically significant functionality between the type of innovation and the size of an enterprise.

\section{Scientific research results and Discussion.}

The H1 hypothesis verification:

In our research we assume that the size of enterprise is an important factor affecting the innovation activities. Large companies have bigger opportunities to invest into innovation activities from profit, loans or EU funding. On the contrary, small businesses have worse conditions to obtain external funding. To verify the $\mathrm{H} 1$ hypothesis a Chi-square test statistical method has been used (tables 1-4). 
Table 1 - Sources of financing the innovation in SMEs (developed by authors)

\begin{tabular}{|c|c|c|c|c|c|c|}
\hline The size of enterprise / Innovation financing & Profit & $\begin{array}{c}\text { EU } \\
\text { funding }\end{array}$ & $\begin{array}{c}\text { Bank } \\
\text { loan }\end{array}$ & $\begin{array}{c}\text { Subsidies from } \\
\text { government }\end{array}$ & Others & \multirow{2}{*}{$x^{2}$} \\
\cline { 1 - 8 } Micro-sized enterprise (up to 10 employees) & 167 & 23 & 99 & 17 & 21 & \\
\hline Small-sized enterprise (up to 50 employees) & 100 & 28 & 70 & 11 & 3 & \\
\hline Medium-sized enterprise (up to 250 employees) & 46 & 24 & 40 & 8 & 1 & 0,00024 \\
\hline
\end{tabular}

Table 2 - Sources distribution comparison for micro-sized enterprise financing (developed by authors)

\begin{tabular}{|c|c|c|c|}
\hline Micro-sized enterprise & Real frequencies & Anticipated frequencies & \multirow{6}{*}{$x^{2}$} \\
\hline Profit & 167 & 65,4 & \\
\hline EU funding & 23 & 65,4 & \\
\hline Bank loan & 99 & 65,4 & \\
\hline Subsidies from government & 17 & 65,4 & \\
\hline Others & 21 & 65,4 & \\
\hline Together & 327 & 327 & $6,55.10^{-57}$ \\
\hline
\end{tabular}

Table 3 - Sources distribution comparison for small-sized enterprise financing (developed by authors)

\begin{tabular}{|c|c|c|c|}
\hline Small-sized enterprise & Real frequencies & Anticipated frequencies & \multirow{6}{*}{$X^{2}$} \\
\hline Profit & 100 & 42,4 & \\
\hline EU funding & 28 & 42,4 & \\
\hline Bank loan & 70 & 42,4 & \\
\hline Subsidies from government & 11 & 42,4 & \\
\hline Others & 3 & 42,4 & \\
\hline Together & 212 & 212 & $9,047.10^{-34}$ \\
\hline
\end{tabular}

Table 4 - Sources distribution comparison for medium-sized enterprise financing (developed by authors)

\begin{tabular}{|c|c|c|c|}
\hline Medium-sized enterprise & Real frequencies & Anticipated frequencies & \multirow{6}{*}{$x^{2}$} \\
\hline Profit & 46 & 23,8 & \\
\hline EU funding & 24 & 23,5 & \\
\hline Bank loan & 40 & 23,8 & \\
\hline Subsidies from government & 8 & 23,8 & \\
\hline Others & 1 & 23,8 & \\
\hline Together & 119 & 118,7 & $4,028 \cdot 10^{-13}$ \\
\hline
\end{tabular}

The Chi-square ( $\mathrm{X} 2$ ) test of independence has confirmed that there is a statistically significant functionality between the size of an enterprise and the way of financing the innovation, because the $p(0.00024)<\alpha(0.05)$. The Fig. 1 shows that micro-sized enterprises are significantly more inclined to financing innovation from their own profits, bank loans or from other sources. On the contrary, small and medium-sized enterprises have never used other resources at all, which is reflected in the declining trend in the Fig. 1. Within the small businesses the burden of innovation financing is on their own sources from profits and bank loans. Both of these sources are, however, sharply declining in a trend that is seen in Fig.1. Within the medium-sized enterprises it can be seen that the EU funding usage is becoming equivalent to the most commonly preferred source of financing such as, income and bank loans. We can observe that along with the size of an enterprise the share of innovation financing out of profits and bank loans is significantly decreasing. The box plot - graph 
Є. Іванова, М. Кордош. Інноваційна політика малих та середніх підприємств Словаччини в контексті інноваційної політики Європейського Союзу

n. 2 shows that, in general, businesses mostly are drawing resources from their profits and bank loans. The EU funding and subsidies from the government are significantly behind.

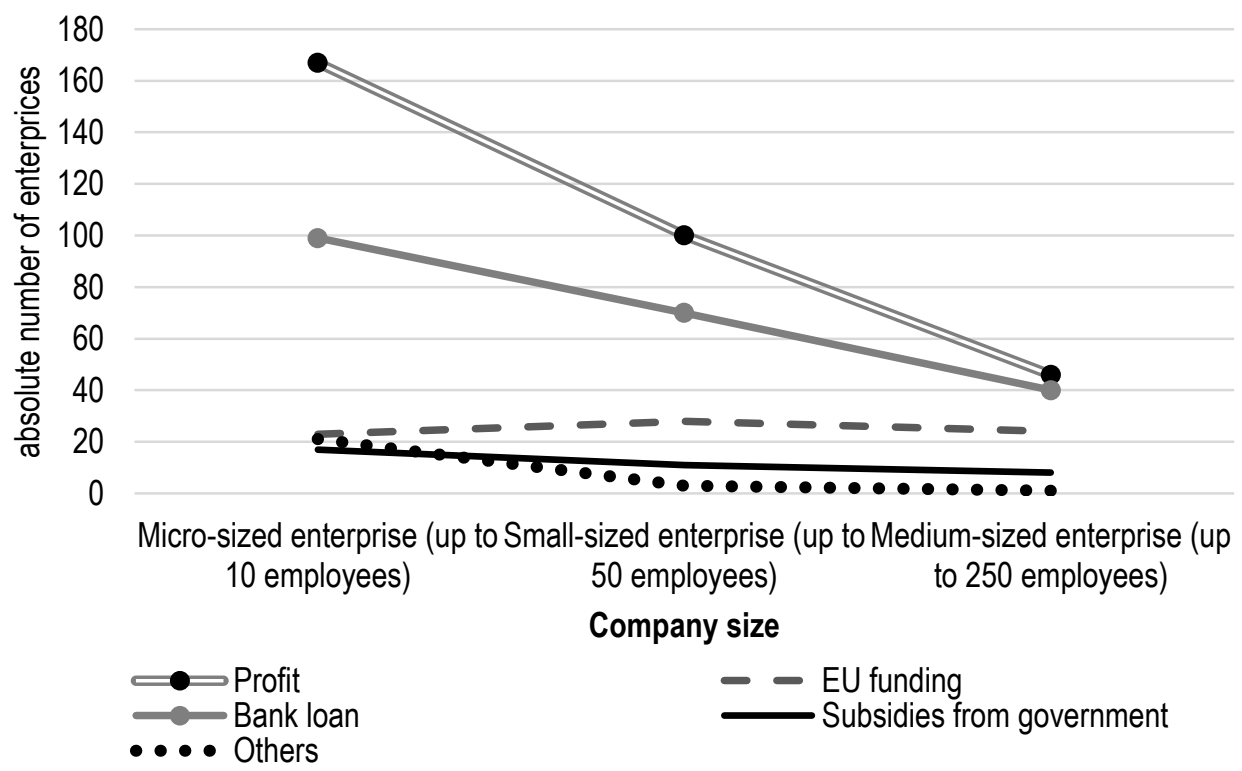

Figure 1 - Innovation financing sources trends in SMEs (developed by authors)

The Chi-square test of proper correlation has confirmed in all three cases that there is a statistically significant difference within the use of different types of funding, because all types of enterprises are showing $p<a(0.05)$. This trend can also be seen in the chart below. An interesting trend is that along with the size of an enterprise the difference among the different sources of financing (Figure 1) gradually are whipping out because the $p$-value is decreasing significantly.

Next, we examined whether different types of funding, regardless of company size are preferred proportionally. Because the subgroups are small to verify the normality, the non-parametric Kruskal rightWallis test has been used for the comparison (Table 5).

Table 5 - Kruskal-Wallis test (developed by authors)

\begin{tabular}{|c|c|c|c|c|c|c|}
\hline \multicolumn{7}{|c|}{ Kruskal-Wallis test } \\
\hline $\begin{array}{c}\text { Financial } \\
\text { source }\end{array}$ & Profit & EU funding & Bank loan & $\begin{array}{c}\text { Subsidies from } \\
\text { government }\end{array}$ & Others & \\
\hline median & 100 & 24 & 70 & 11 & 3 & \\
\hline p-value & \multicolumn{7}{|c|}{0,014404} \\
\hline
\end{tabular}

The Kruskal-Walis non-parametric test has confirmed that enterprises do not prefer individual financial sources on equivalent bases since $p(0.014404)<a(0.05)$. A comparison of subgroups by means of Neményi test shows that there is a statistically significant difference between the financing of innovation and profit from other sources (Table 6). Other types of financing are equivalent to each other. The differences being observed are not statistically significant. The $\mathrm{H} 1$ has been confirmed. 
Розділ 3 Інноваційний менеджмент

Table 6 - Nemenyi test (developed by authors)

\begin{tabular}{|l|c|c|c|c|c|}
\hline $\begin{array}{l}\text { Nemény test } \\
\text { outcomes }\end{array}$ & Profit & EU funding & Bank loan & Subsidies from government & Others \\
\hline Profit & - & - & - & - & - \\
\hline EU funding & 2,0656 & - & - & - & - \\
\hline Bank loans & 0,6455 & 1,4201 & - & - & - \\
\hline $\begin{array}{l}\text { Subsidies from } \\
\text { government }\end{array}$ & 3,6148 & 1,5492 & 2,9693 & - & - \\
\hline Others & 4,0021 & 1,9365 & 3,3566 & 0,3873 & - \\
\hline
\end{tabular}

\begin{tabular}{|l|c|c|c|c|c|}
\multicolumn{1}{|c}{ q-crit = 3,858} & EU funding & Bank loan & Subsidies from government & Others \\
\hline $\begin{array}{l}\text { Nemény } \\
\text { outcomes }\end{array}$ & Profit & - & - & - & - \\
\hline Profit & no & - & - & - & - \\
\hline EU funding & no & no & - & - & - \\
\hline Bank loans & no & no & no & - & - \\
\hline $\begin{array}{l}\text { Subsidies from } \\
\text { government }\end{array}$ & sig. & no & no & no & - \\
\hline Others
\end{tabular}

If the stated value of test criteria in the table is greater than the critical value of Neményi method test criteria for qk, $\infty$ (0.05); so q-crit $=3,858$; among subgroups there is a statistically significant difference. As we can see, the only value that exceeds this critical value is 4,0021 . So only among these subgroups there is a statistically significant difference.

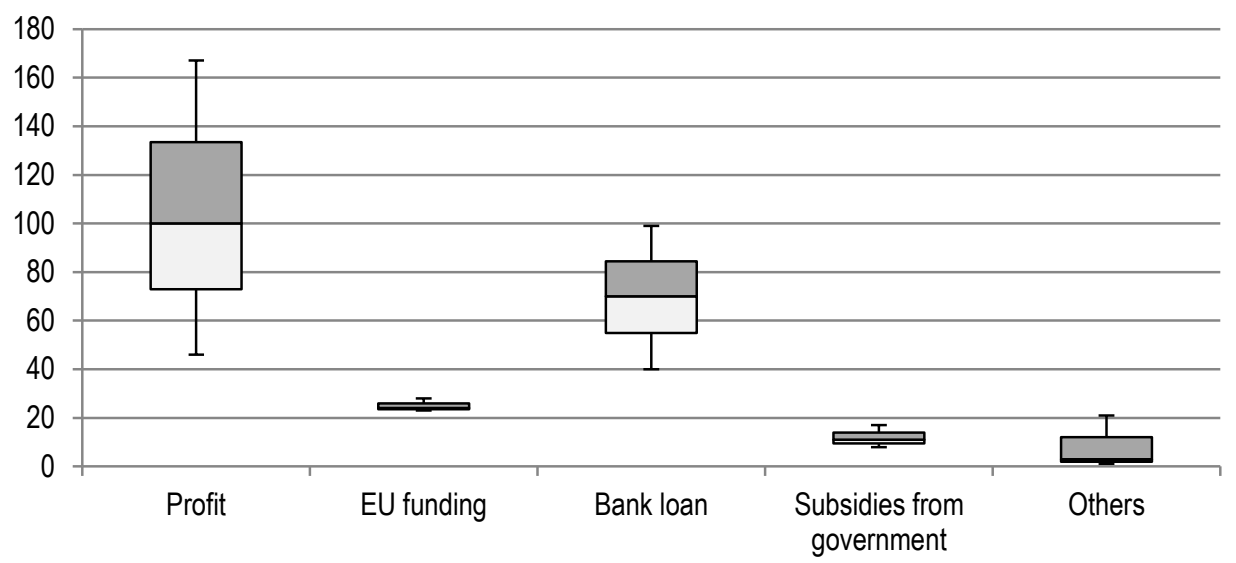

Figure 2 - Funding sources comparison of all kinds of enterprises (developed by authors)

The box plot chart has a considerable information value especially while comparing many subgroups, where we can see their distribution and range. It is divided into quartiles, i.e. quarters. Horizontal line intersecting the boxes through represents the median (middle value) - the second quartile $\times 0.5$. Lower and upper parts of the box visualize the first quartile $\times 0.25$ (lower quarter) and the 
third quartile $x 0.75$ (upper quarter). The lower part of the line represents the minimum and upper part of the segment the maximum. Even if it seems from the figures that the profit is positioned significantly higher than other sources, tests have shown that only profit and other sources of funding significantly differ from each other.

The observed facts within the sources of funding for SMEs by means of statistical methods are shown graphically in the Figure 3.

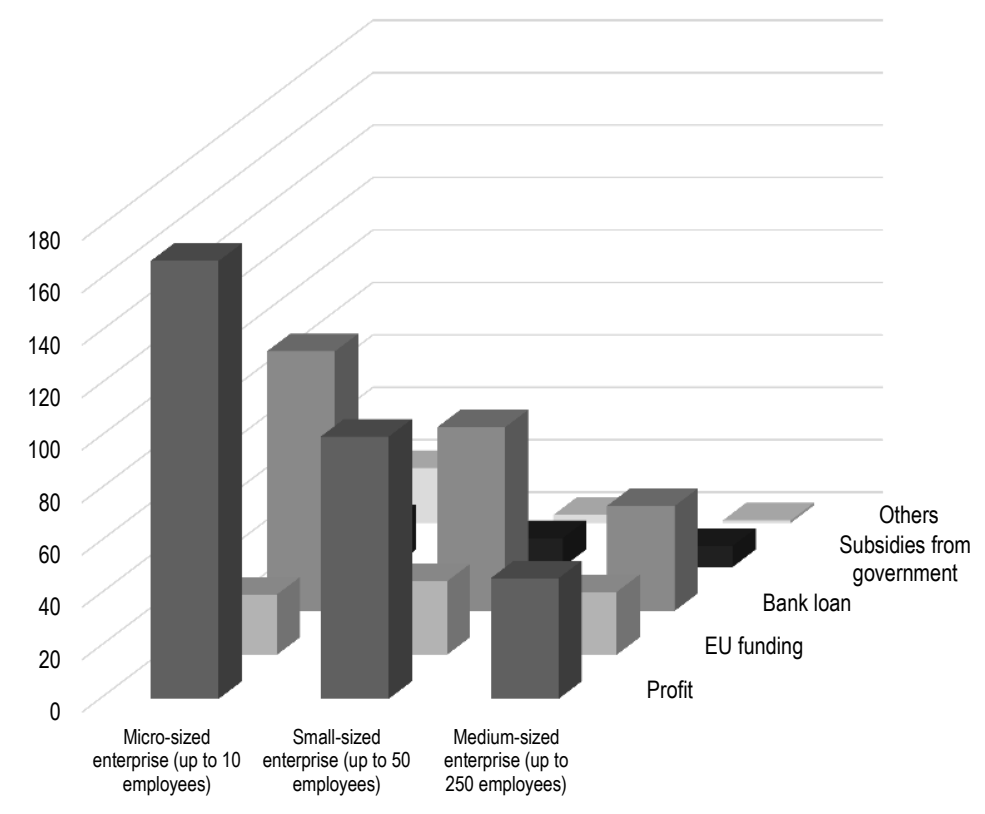

Figure 3 - Sources distribution comparison for micro-sized enterprise financing

(developed by authors)

The Figure shows that in all size categories of enterprises profit is the main source of funding regarding innovation activities, most notably it is in micro-sized enterprises, which are based on selffinancing. Next, in terms of significance, profit is followed by bank loans. Subsidies from governments and funding are the least significant sources of funding regarding innovation activities in all size forms of enterprises; it is related to relatively large administration and lobbing activities being necessary to obtain those sources.

In the context of the above analysis, it can be stated that partially even the hypothesis $\mathrm{H} 1 \mathrm{a}$ has not been confirmed. In addition to the statistical evidence it may be noted that 92 respondents representing $14 \%$ of the respondents' sample (529) were drawing the EU funding as another source of innovation activities funding; for example that is relatively small value compared to the value of profit representing almost $60 \%$ and the bank loan $-39.5 \%$. In some obtained questionnaires not all the questions were filled in and answered that is why the total sum can vary a little bit.

The $\mathrm{H} 2$ hypotheses verification: in our research, we assume that the selected type of innovation is influenced by the size category of an enterprise because not all types of innovation are proportionally demanding for funding. We also assume that the distribution of innovation types is not uniform for the 
particular types of enterprises. To test the $\mathrm{H} 2$ hypothesis, a Chi-square test statistical method has been used again.

Table 7 - Types of innovation in SMEs (developed by the author)

\begin{tabular}{|c|c|c|c|c|c|}
\hline $\begin{array}{c}\text { The size of enterprise/ } \\
\text { Type of innovation }\end{array}$ & $\begin{array}{c}\text { Production } \\
\text { Innovation }\end{array}$ & $\begin{array}{c}\text { Processing } \\
\text { Innovation }\end{array}$ & $\begin{array}{c}\text { Organization } \\
\text { Innovation }\end{array}$ & $\begin{array}{c}\text { Marketing } \\
\text { Innovation }\end{array}$ & $X^{2}$ \\
\hline Micro-sized enterprise (up to 10 employees) & 66 & 57 & 85 & 100 & 49 \\
\hline Small-sized enterprise (up to 50 employees) & 53 & 41 & 49 & 28 & 0,2171 \\
\hline Medium-sized enterprise (up to 250 employees) & 33 & 20 & 21 & 28 & \\
\hline
\end{tabular}

Because the probability value is bigger than the significance level, $p(0.2171)>a(0.05)$, there is no statistically significant functionality between the type of innovation and the size of an enterprise. That means that the type of innovation is not dependent on the size of an enterprise. Also in the box plot it is shown that the particular types of innovation occur at a relatively similar level.

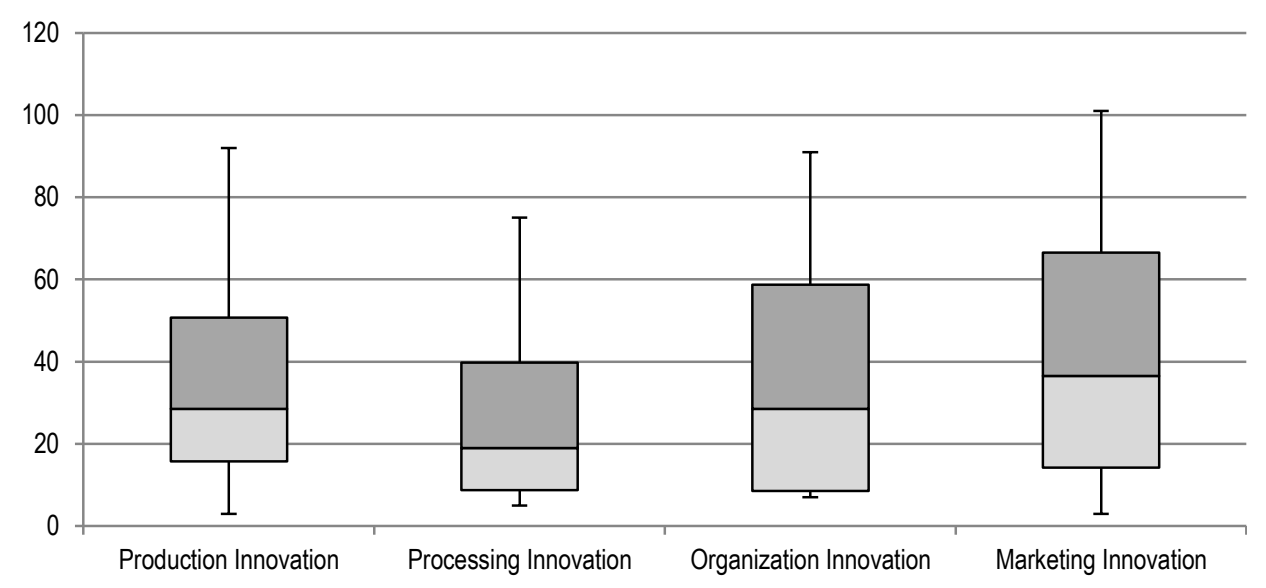

Figure 4 - Types of innovation comparison for all kinds of enterprises (developed by the author)

The box-plot shows that the particular types of innovation occur at a relatively similar level, the values are shown in the table above - Table 6 . To verify the distribution uniformity of innovation types being preferred in individual enterprises, the $x 2$ test of proper correlation has been used. The results are summarized in tables below (Table 8).

Table 8 - Real and anticipated frequencies (developed by the author)

\begin{tabular}{|c|c|c|c|}
\hline Micro-sized enterprise & Real frequencies & Anticipated frequencies & \multirow{3}{*}{$\mathcal{X}^{2}$} \\
\hline Production Innovation & 66 & 77 & \\
\hline Processing Innovation & 57 & 77 & \\
\hline Organization Innovation & 85 & 77 & 0,002333 \\
\hline Marketing Innovation & 100 & 77 & 308 \\
\hline Together & 308 & &
\end{tabular}


Є. Іванова, М. Кордош. Інноваційна політика малих та середніх підприємств Словаччини в контексті інноваційної політики Європейського Союзу

Continued of Table 8

\begin{tabular}{|c|c|c|c|}
\hline Small-sized enterprise & Real frequencies & Anticipated frequencies & \multirow{5}{*}{$x^{2}$} \\
\hline Production Innovation & 53 & 48 & \\
\hline Processing Innovation & 41 & 48 & \\
\hline Organization Innovation & 49 & 48 & \\
\hline Marketing Innovation & 49 & 48 & \\
\hline Together & 192 & 192 & 0,663175 \\
\hline Production Innovation & Real frequencies & Anticipated frequencies & $x^{2}$ \\
\hline Processing Innovation & 33 & 25,5 & \\
\hline Organization Innovation & 20 & 25,5 & \\
\hline Marketing Innovation & 21 & 25,5 & \\
\hline Together & 28 & 25,5 & \\
\hline Production Innovation & 102 & 102 & 0,218494 \\
\hline
\end{tabular}

Since $p(0.00233)<a(0.05)$ there is a statistically significant difference between the real and proportional distribution of investments into the particular types of innovation. However the marketing innovations are significantly the most preferred type of innovation in micro-enterprises. It can be seen in Figure 5 .

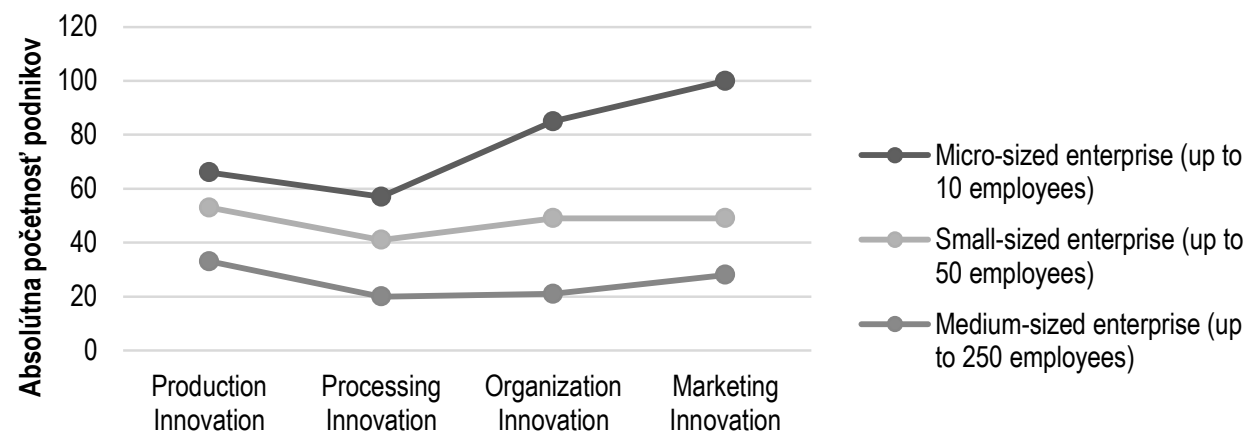

Type of innovation

Figure 5 - The type of innovation dependency on the size of an enterprise (own processing)

Since $p(0.663)>a(0.05)$ there is not a statistically significant difference between the real and proportional distribution of investments into the particular types of innovation regarding small-sized enterprises. Small enterprises are investing into different types of innovation on equivalent bases.

Since $p(0.2185)>a(0.05)$ there is not a statistically significant difference between the real and proportional distribution of investments into the particular types of innovation regarding medium-sized enterprises. Medium-sized enterprises are investing into different types of innovation on equivalent bases. It is also seen in Figure 5.

In the next step, we compared the differences between the types of innovation together within all enterprises regardless of the size of enterprise (Table 9$)$.

Considering that $p(0.853045)>a(0.05)$ it does not represent a statistically significant difference in individual types of innovation implemented in SMEs. Tests have shown that, in general, for all kinds of enterprises together, there is no statistically significant difference between investing into different types of innovation. 
Table 9 - Kruskal-Walis test

\begin{tabular}{|c|c|c|c|c|}
\hline \multicolumn{5}{|c|}{ Kruskal-Wallis test } \\
\hline Type of Innovation & $\begin{array}{c}\text { Production } \\
\text { Innovation }\end{array}$ & $\begin{array}{c}\text { Processing } \\
\text { Innovation }\end{array}$ & $\begin{array}{c}\text { Organization } \\
\text { Innovation }\end{array}$ & $\begin{array}{c}\text { Marketing } \\
\text { Innovation }\end{array}$ \\
\hline median & 53 & 41 & 49 & 49 \\
\hline p-value & \multicolumn{4}{|c|}{0,853045} \\
\hline alfa & \multicolumn{4}{|c|}{0,05} \\
\hline sig. & \multicolumn{4}{|c|}{ no } \\
\hline
\end{tabular}

We assumed that there is a statistically significant functionality between the type of innovation and enterprise size; based on previous statistical analyzes the $\mathrm{H} 2$ hypothesis has not been confirmed conceptually for all enterprises. Partially it has been confirmed only for micro-enterprises, which investments into marketing innovation have leaped significantly This finding is logical, since it is obvious that the smaller the company, the more visible the company wants to be by using the marketing tools.

Conclusions and directions of further researches. In all developed countries it is generally known that the successful economy is determined by its level of competitiveness, which greatly depends on innovation performance of a particular economy. For enterprises being the main actors of innovation performance it is very important to obtain resources for their innovation activities. In our research we focused on the identification of financial sources within SMEs in Slovakia and on finding out what structure these sources within SMEs are used the most, while taking into account the objectives and instruments of EU innovation policy we assumed that this kind of instrument will be used in SMEs to a large extent. The research has showed that European financial sources are used only about by $17 \%$ of the tested companies. Other statistical analysis findings in the context of $\mathrm{H} 2$ verification suggest that the form of financial resources being used depends on the size of a company, further, we found out that funding is mostly being spent on marketing innovation; regarding the kind of executed innovation, individual size categories of SMEs do not differ significantly. Marketing innovation is used the most commonly by micro-sized enterprises in Slovak business environment.

As a paper outcome we recommend that the Slovak business environment should more focus on external financing sources for SMEs such as EU funding programs and other alternative options how to finance the SMEs development such as the venture capital usage.

We can highlight that the EU economies are following a long-established trend of restructuring away from the primary and secondary sectors and towards services and high value-added products. But manufacturing is still an important economic sector of the Community for production, trade and employment. In recent years the industry has operated against a background of slow growth of demand, rising unemployment, increasing international competition and rapid changes brought about by technological progress. Although these are problems which to some extent are shared by all members of the Community, industrial policy still remains largely a national responsibility. The Community has taken steps to ensure that, in accordance with a system of open and competitive markets, the conditions and the legal framework necessary for speeding up the structural adjustment and competitiveness of European industry will develop.

Further research will be devoted to exploring the role of SMEs within the other EU common and coordinating policies such as Industry and Regional policies. Taking into account that questions of financial relations between investors and companies are among the most complicated ones, crucial emphasis should be also paid to researching peculiarities of Innovation policy and Strategy 2020 symbiosis and synergies. 
Є. Іванова, М. Кордош. Інноваційна політика малих та середніх підприємств Словаччини в контексті інноваційної політики Європейського Союзу

1. Balaz, P. (2013). International Trade in the World Crisis of the 21st Century. Ekonomicky casopis, Vol.61, Iss.10, 1079-1083.

2. Bockova, N., \& Zizlavsky, O. (2016). Innovation and Financial Performance of a Company: A Study from Czech Manufacturing Industry. Transformation in Business and Economics, 15 (3(39)), 156-175.

3. Brancati, E. (2015), Innovation Financing and the role of relationship lending for SMEs. Small Business Economics, 44, $449-473$

4. Chesbrough, H., \& Appleyard, M. (2007). Open innovation and strategy. California Management Review, 50 (1), 57-76.

5. Cincera, M., \& Santos, A., (2016). Institute for development and international relations. IRMO Occasional Papers, 1. Brussels: Brussels School of Economics and Mangement.

6. European Commission. (2016). EU Innovation policy. ec.europa.eu. Retrieved from https://ec.europa.eu/growth/industry/innovation_en.

7. Fojtíková, L. (2014). Performance and growth of the Eurozone export. 17TH International conference Enterprise and competitive environment 2014 Book Series: Procedia Economics and Finance, Vol. 12, 154-163.

8. Foreman-Peck, J. (2013). Effectiveness and efficiency of SME innovation policy. Small Bus Econ, 41(1), 55-70, DOI: 10.1007/s11187-012-9426-z.

9. Gupta, P.D. et al. (2013). Firm growth and its determinants. Journal of Innovation and Entrepreneurship, 15 (2), 142-161.

10. Habánik, J., Kordoš, M., \& Hosták, P. (2016). Competitiveness of Slovak economy and regional development policies. Journal of International Studies, 9 (1), 144-155.

11. Hall, B.H. (2010). The Financing of Innovative Firms. Review of Economics and Institutions, 1(1), 1-30.

12. Havierniková, K., \& Srovnaliková, P. (2016). Selected categories of levies and their impact on economic results of small and medium-sized enterprises. Actual Problems of Economics, 11(185), 214-221.

13. Hnát, P. (2013). Balance of Payments Imbalances as a Challenge for Economic Governance. Changes in Governance: In the Context of the Global Crisis, 79-91

14. Krpálek, P., \& Krpálková Krelová, K. (2016). Possibilities for Developing Business Potential in Economic Education. Examples of Implementation in Slovakia and the Czech Republic, Economics and Sociology, Vol. 9, No 4, 119-133, DOI: 10.14254/2071-789X.2016/9-4/7.

15. Lee, N., Sameen, H., \& Cowling, M. (2015). Access to finance for innovative SMEs since the financial crisis. Research Policy, Vol. 44, 370-380.

16. Lesáková, L'. (2011). Norms promoting creativity and innovations in small and medium enterprises. In: Studia Universitatis Vasile Goldis, Arad, Stiinte Economice, 21(1), 44-50.

17. Madrid-Guijarro, A., Garcia-Perez-de-Lema, D., \& Van Auken, H. (2016). Financing constraints and SME innovation during economic crises. Academia-Revista Latinoamericana de Administracion, 29 (1), 84-106.

18. Mancusi, M.L., \& Vezzulli, A. (2014). R\&D and credit rationing in SMEs. Economic Inquiry, 52 (3), 1153-1172.

19. Mynarzova, M., \& Stverkova, H. (2015). Public Support as an Important Factor for Competitiveness of SMEs in the European Union. Aktualne problemy podnikovej sfery 2015, 452-461.

20. Neumann, P. (2015). The impact of structural changes in national economies on globalization character. Globalization and its socio-economic consequences, PTS I AND II, 498-504

21. Niklewicz-Pijaczyńska, M., \& Wachowska, M. (2014). The role of clusters in stimulating breakthrough innovation in enterprises, Journal of International Studies, Vol. 7, No 1, 58-69, DOI: 10.14254/2071-8330.2014/7-1/5.

22. Obadi, S.M., \& Korcek, M. (2016). The "Revealed" Comparative Advantage and Competitiveness of the EU's International Trade visa vis the USA. Ekonomicky casopis, Vol.64, Iss. 5, 397-422.

23. Petronela, N.A., \& Cojanu, V. (2013). Supporting regional competitiveness through innovation. Case study: Sud Muntenia. Journal of International Studies, Vol. 6, No 1, 51-58.

24. Radas, S., Anic, I., tafro, A., \& Wagner, V. (2015). The effects of public support schemes on small and medium enterprises. Technovation, Vol. 38, 15-30.

25. Spithoven, A., Vanhaverbeke, W., \& Roijakkers, N. (2013). Open innovation practices in SMEs and large enterprises. Small Business Economics, 41(3), 537-562.

26. Tauser, J., Arltova, M., \& Zambersky, P. (2015). Czech exports and German GDP: a closer look. Prague Economic Papers, Vol. 24, Iss. 1, 17-37

27. Teirlinck, P., \& Spithoven, A. (2013). Research collaboration and R\&D outsourcing: Different R\&D personnel requirements in SMEs. Technovation, 33(4), 142-153.

28. Tödtling, F., \& Kaufman, A. (2002). SMEs in Regional Innovation system and the role of Innovation Suport - The case of Epper Austria. Journal of technology transfer, 27 (1), 15-26.

29. Vermoesen, V., Deloof, M., \& Laveren, E. (2013). Long-term debt maturity and financing constraints of SMEs during the global financial crisis. Small Business Economics, 41(2), 433-448.

30. Vojtovič, S. (2016). The Impact of The Structural Funds on Competitiveness of Small and Medium-Sized Enterprises. Journal of Competitiveness, 8 (4), 30-45. 
$\boldsymbol{\epsilon . l в а н о в а , ~ I n g . , ~ C S c . , ~ а с и с т е н т , ~ з а в і д у в а ч ~ к а ф е д р и ~ е к о н о м і к и , ~ ф а к у л ь т е т ~ с о ц і а л ь н и х ~ т а ~ е к о н о м і ч н и х ~ в і д н о с и н , ~}$ Тренчанський університет Олександра Дубчека (м. Тренчин, Словацька Республіка);

M. Kopdou, Ing., PhD, асистент кафедри державного управління та регіональної економіки, факультет соціальних та економічних відносин, Тренчанський університет Олександра Дубчека (м. Тренчин, Словацька Республіка)

Інноваційна політика малих та середніх підприємств Словаччини в контексті інноваційної політики Європейського Союзу

у статті визначено фрінансові джерела, що використовуються малими та середніми підприємствами (SMEs) Словаччини для фрінансування інновацій. Визначено джерела, що мають основне значеня для фрінансування SMEs. Встановлено типи інновацій, в які найчастіше інвестують малі та середні підприємства. У ході дослідження було проведено опитування. Отримані результати були оброблені за допомогою тесту Chi-square.

Ключові слова: інновації, фінансові джерела, інноваційна політика, види інновацій.

E. Иванова, Ing., CSc., ассистент, заведующий кафедрой экономики, фракультет социальных и экономических отношений, Тренчанский университет Александра Дубчека (г. Тренчин, Словацкая Республика);

M. Kopdou, Ing., PhD, ассистент кафедры государственного управления и региональной экономики, факультет социальных и экономических отношений, Тренчанский университет Александра Дубчека (г. Тренчин, Словацкая Республика)

Инновационная политика малых и средних предприятий Словакии в контексте инновационной политики Европейского Союза

В статье определены финансовые источники, используемые малыми и средними предприятиями (SMEs) Cловакии для финансирования инноваций. Определены источники, имеющие основополагающее значеня для финансирования SMES. Установлено типы инноваций, в которые чаще всего инвестируют малые и средние предприятия. В ходе исследования был проведен опрос. Полученные результаты были обработаны с помощью теста Chi-square.

Ключевые слова: инновации, финансовые источники, инновационная политика, виды инноваций.

Отримано 18.03.2017 p. 